\title{
Proposals for follow-up of graduates in the institutional development plans of federal universities
}

\author{
Proposições de acompanhamento de egressos nos planos de \\ desenvolvimento institucional das universidades federais
}

\section{Propuestas de seguimiento de egresados en los planes de desarrollo institucional de las universidades federales}

\author{
Lausemar Freitas Sobrinho Freire ${ }^{1}$ (D), Kellcia Rezende Souza ${ }^{1}$ (D) \\ ${ }^{1}$ Federal University of Grande Dourados, Dourados, Mato Grosso do Sul, Brazil. \\ Corresponding author: \\ Lausemar Freitas Sobrinho Freire \\ Email: lausemarfreitas@gmail.com
}

Como citar: Freire, L. F. S., \& Souza, K. R. (2021). Proposals for follow-up of graduates in the institutional development plans of federal universities. Revista Tempos e Espaços em Educação, 14(33), e16235.

http://dx.doi.org/10.20952/revtee.v14i33.16235

\begin{abstract}
Universities fulfill the mission of carrying out teaching, research and extension based on a recognition of education as an instrument of social transformation. In this sense, public institutions are being increasingly charged for the efficiency and effectiveness of their actions. From this context, evaluation mechanisms emerge to measure effectiveness and assign concepts to Higher Education Institutions (HEIs). From the recognition of the instruments that recommend the institutional evaluation in Brazil, the mention of the planning actions, the Institutional Development Plan (PDI) becomes strategic, and in this it is observed as an indicator to be inserted, the accompaniment of graduates of undergraduate and postgraduate courses. The objective of the research is to identify the actions and goals foreseen in the IDPs of Brazilian federal universities in the Southeast region to follow up their graduates. The development of this work was through the qualitative approach with documentary research, by searching the university websites for the available institutional information. The results point to two distinct contexts, in which most of the researched institutions inserted in their macro-document the theme, one group aims to implement the policy and another group intends to advance to other follow-up stages, since it is a policy already institutionalized.
\end{abstract}

Keywords: Alumni. Planning and evaluation. POI. University management.

\section{RESUMO}

O reconhecimento da demanda da avaliação das Instituições de Ensino Superior (IES) no Brasil, fez com que o Plano de Desenvolvimento Institucional (PDI) fosse compreendido como um dos 
principais instrumentos estratégicos para essa finalidade, e neste observa-se como indicador a ser inserido, o acompanhamento de egressos dos cursos de graduação e pós-graduação. Nessa vertente, o objetivo da pesquisa consiste em identificar as ações e metas previstas nos PDIs de 19 universidades federais brasileiras da região Sudeste para o acompanhamento de seus egressos. Para tanto, foi realizada, mediante abordagem qualitativa, uma pesquisa bibliográfica e pesquisa documental. Os resultados sinalizam que a maioria das instituições pesquisadas inseriu em seu macrodocumento de planejamento o tema, porém, com ações diferenciadas, dentre elas, destacamos dois grupos: um grupo visa à implementação da política e o outro pretende avançar para outras etapas do acompanhamento.

Palavras-chave: Ex-alunos. Gestão universitária. PDI. Planejamento e avaliação.

\section{RESUMEN}

Las universidades cumplen la misión de llevar a cabo la enseñanza, la investigación y la extensión basadas en el reconocimiento de la educación como instrumento de transformación social. En este sentido, las instituciones públicas están siendo acusadas cada vez más por la eficiencia y efectividad de sus acciones. A partir de este contexto, surgen mecanismos de evaluación para medir la efectividad y asignar conceptos a las instituciones de educación superior (IES). Desde el reconocimiento de los instrumentos que recomiendan la evaluación institucional en Brasil, la mención de las acciones de planificación, el Plan de Desarrollo Institucional (PDI) se vuelve estratégico, y en esto se observa como un indicador a insertar, el acompañamiento de egresados de cursos de pregrado y posgrado. El objetivo de la investigación es identificar las acciones y objetivos previstos en los desplazados internos de las universidades federales brasileñas en la región sudeste para dar seguimiento a sus graduados. El desarrollo de este trabajo fue a través del enfoque cualitativo con la investigación documental, buscando en los sitios web de la universidad la información institucional disponible. Los resultados apuntan a dos contextos distintos, en los que la mayoría de las instituciones investigadas insertaron en su macrodocumento el tema, un grupo tiene como objetivo implementar la política y otro grupo tiene la intención de avanzar a otras etapas de seguimiento, ya que ya es una política institucionalizado.

Palabras clave: Alumni. Gestión universitaria. Planificación y evaluación. POI.

\section{INTRODUCTION}

Higher Education plays an essential role in the social, cultural and citizenship education of its students and, therefore, universities have incorporated in their management actions, systematic monitoring, planning, evaluation, to meet social demands and to be accountable to regulatory agencies.

In this context, the National System of Higher Education Assessment (SINAES) was instituted, Law No. 10,861 of 2004, with the objective of ensuring a national process of assessment of higher education institutions, undergraduate courses and academic performance of his students.

Picawy (2007) emphasizes that the text of the SINAES Law states that the evaluation of Higher Education Institutions (HEls) will have as its primary objective the identification of the profile and meaning of action, specified in its different institutional dimensions and that the HEl must compulsorily prepare its Institutional Development Plan (IDP). For Dal Magro \& Rausch (2012), the IDP is highly strategic, due to the information disclosed, the planned actions, which is why it is constantly being perfected and improved by higher education institutions.

Dal Magro \& Rausch (2012) describe the different dimensions of the IDP: institutional profile; institutional management; student service policies; academic organization; infrastructure; financial and budgetary aspects; and institutional assessment and development. And punctually, in the dimension that refers to the assistance to students, the indicator, monitoring of graduates, is provided for. 
It is important to add that in the strategies boosted by SINAES, specifically in the instrument of external institutional assessment, it is also foreseen, as well as in the IDP, the follow-up of the graduate. In this bias, it is necessary to use adequate mechanisms to know the opinion of graduates about the formation received, both curricular and ethical, to know the occupation rate among them, to establish a relationship between the occupation and the professional formation received. In addition, consider the opinion of employers to review education plans and programs, and whether there are updating and continuing education activities (INEP, 2004).

Thus, SINAES has a series of complementary instruments for evaluation. Thus, the integration of instruments allows for attributing some concepts, ordered on a scale with five levels, to each of the dimensions and to the set of these evaluated (INEP, 2015). In this sense, IDP and external institutional evaluation instrument are articulated, mechanisms foreseen for the evaluation of universities, from the perspective of the effective monitoring of graduates in HEls.

However, the survey on the subject has a remarkably unprecedented character, as studies and research are scarce and systematic and comparative survey of graduates is little observed in Brazilian higher education institutions (Machado, 2010).

To examine a given context, the researcher needs to have a keen eye to scientifically validate their studies. Thus, from the information available in the 2018 Higher Education Census, data on students enrolled in the Southeast region, which has the largest academic contribution and has $3,755,153$ students enrolled in on-site and distance undergraduate courses in public and private HEls, numbers that collaborate to identify the typical student of undergraduate courses in the faceto-face modality, regarding their profile, this student attends a bachelor's degree, predominantly female and attends the night shift, as for the typical distance undergraduate student, attends a teaching degree course (INEP, 2019). The justification for the focus on federal universities in the Southeast is because this region has the largest number of students enrolled in higher education and universities can contribute, based on the constitution of their respective IDPs and planning of their institutional actions, with a representative perspective of the accompaniment of its alumni. It is necessary to justify the criteria that led to the selection of the Southeast region.

In 2018, more than one million and two hundred thousand students completed undergraduate higher education in Brazil (INEP, 2019), based on these data, the question is: what actions the federal universities in the Southeast region have planned to follow the professional and academic trajectory of thei graduates?

This contextualization and justification lead to the following research question: What propositions have federal universities in the Southeast included in their Institutional Development Plans for monitoring graduates?

The objective of the research is to identify the actions and goals foreseen in the IDPs of federal universities in the Southeast region for monitoring their graduates.

\section{METHODOLOGY}

This study aims to identify the actions and goals provided for in the IDPs of federal universities in the Southeast region for monitoring their graduates, as this is the region with the greatest academic contribution. And, to achieve the proposed objective, a qualitative approach was used, and a bibliographic and documentary research was carried out. The collected data were analyzed from the following categories of analysis: identification of federal universities in the Southeast region, verification of current IDPs, analysis of actions planned for monitoring graduates to prepare a framework with the main proposals for implementation.

Bibliographic researches are developed based mainly on scientific articles and books, so that when consulting the previously elaborated material, other results are produced based on the contributions of several authors (Gil, 2002). 
It is observed that documentary research can be re-elaborated according to the object of the study and make use of elements that have not yet received an analytical treatment (Gil, 2002). We sought to use the aforementioned methodology, in this specific case, by proposing an analysis of observable aspects in the IDPs available on the websites of Brazilian federal universities of the Southeast region regarding actions to monitor graduates.

To achieve the proposed objective, the nineteen federal universities in the Southeast were initially identified:

UFABC - Federal University of ABC

UFES - Federal University of Espírito Santo

UFF - Fluminense Federal University

UFMG - Federal University of Minas Gerais

UFJF - Federal University of Juiz de Fora

UFLA - Federal University of Lavras

UFOP - Federal University of Ouro Preto

UFRJ - Federal University of Rio de Janeiro

UFRRJ - Federal Rural University of Rio de Janeiro

UFSCar - Federal University of São Carlos

UFSJ - Federal University of São João del-Rei

UFU - Federal University of Uberlândia

UFV - Federal University of Viçosa

UFVJM - Federal University of Vales do Jequitinhonha and Mucuri

UNIFAL - Federal University of Alfenas

UNIFEI - Federal University of Itajubá

UNIFESP - Federal University of São Paulo

UNIRIO - Rio de Janeiro State Federal Univeristy

UFTM - Federal University of Triângulo Mineiro

Later, still at this stage, the Institutional Development Plan of each university was also verified. In order to understand how the HEls have planned to develop their actions related to the follow-up of graduates, an incursion into the current IDPs available on the websites of each of the Federal Universities surveyed was necessary. After a search for primary data on university portals, it was intended to recognize the actions and goals proposed to carry out the monitoring of graduates.

Subsequently, to systematize the information collected, it was necessary to draw up a table with the main data obtained from the universities' websites, presenting an overview of how these institutions present the information to the general public and plan to develop actions and goals for the topic.

\section{THEORETICAL REFERENCE}

\section{Management, planning and institutional evaluation in brazilian federal universities}

To provide greater administrative rationality to the application of public resources and better meet institutional objectives, the Brazilian State started to demand from its agencies the application of more qualified and democratic tools in administrative planning and management (Luz, 2016; Costa \& Vidal, 2020). In this sense, the authors argue that the action and accountability of public managers is greater in the face of the challenge of carrying out a management that ensures organizational effectiveness and efficiency.

In this bias, exercising management requires the involvement of its representatives to build monitoring and evaluation mechanisms that promote learning, transparency and accountability and the alignment of implementation arrangements that involve sets of policies, programs, projects, 
and organizations (Brasil, 2009). Therefore, analyzing the educational environment presupposes investigating a complex reality that includes several instances, spaces, dimensions and interests in a given social context (Souza, 2017).

Picawy (2007) and Bizerril (2020) point out that a living university is one that pulsates in the constant search for new answers to increase the quality of academic performance in teaching, research, and extension. In view of its social function in pursuing the progressive strengthening of its commitments to regional and national society, both through the improvement of university planning and management mechanisms, as well as through the transfer of its provided services.

In the university context, there is a set of processes to be carried out satisfactorily, among a wide range of institutional aspects, exemplified by: administrative and personnel management, institutional strategic planning; financial sustainability; internal policies aimed at combating student evasion and adequacy of libraries, laboratories, and classrooms (Sobral \& Ramos, 2012; Andriola, 2014).

Machado (2010) warns that the university must be aware that, in fulfilling its functions and functionalities and, in order to achieve better results and reach higher levels, it can insert assessment mechanisms that serve as a basis for planning for the coming years.

From the improvement of planning, management and evaluation actions, the relevant contribution of the Law of Guidelines and Bases of National Education (LDB), No. 9,394, of December 20, 1996, is inserted, which brought important changes to the structuring national education, emphasizing evaluation processes aimed at improving the quality of teaching and, as a resource for sector regulation, the accreditation of institutions and courses. In this context, the evaluation of higher education assumed a special place among educational policies, whether for the guidance of its broader guidelines or for the concrete actions of the competent agencies of the Ministry of Education (INEP, 2003).

The LDB consolidated, as an essential pillar of higher education, the need for evaluation processes, whether in terms of the orientation of political guidelines aimed at improving teaching, with a view to quality; or as to the definition of accrediting actions of the higher education system by the competent agencies to assess, for supervision and state control (Brasil, 2003).

The university's first responsibility is to build the quality of processes without losing sight of their essential purposes, that is, university autonomy in carrying out their procedures while preserving ethics, and scientific and social relevance (Dias Sobrinho, 2015; Batista \& Kerbauy, 2018).

For Dias Sobrinho (2010), evaluation is the organization's main tool for implementing educational reforms. The author states that to impact society and produce the desired changes, assessment in higher education alters the configurations of curricula, teaching methodologies, formative concepts and practices, management, research policies and priorities, notions of relevance and social responsibility.

Finally, it has to do with the complex and desired transformations not only for higher education itself, but for society in general, in the world of knowledge and economy, both in the present and in the future (Dias Sobrinho, 2010; Batistti, Black, Heinzle, 2017).

In summary, the elaboration, planning, and implementation of management models for dynamic, comprehensive, and multidimensional results represent a great challenge, characterized by the integration of agendas, the alignment of implementing structures and monitoring and evaluation mechanisms, which strengthen social use and strategic awareness (Brasil, 2009).

\section{Institutional Development Plan (IDP)}

The Institutional Development Plan (IDP) is a formal document, established in accordance with the guidelines outlined by Law No. 10,861, of April 14, 2004, making its preparation mandatory for HEls (Soares \& Melo, 2017). The authors continue, stating that, in accordance with art. 16 of 
Decree No. 5.773, of May 9, 2006, the IDP is defined as a document that identifies the HEI, regarding its work philosophy, institutional mission, pedagogical guidelines that should guide its actions, its organizational structure, and the academic activities it develops and/or intends to develop.

In line with the provisions of the SINAES Law, Picawy (2007) emphasizes that the IDP brings the general characterization of the $\mathrm{HEI}$ in a descriptive, consistent character, naming the entire administrative, pedagogical and people constitution that determine the profile of the $\mathrm{HEI}$, it also reaffirms that from IDP emanate the guidelines that guide institutional action. And for Mizael et al. (2013) and Dias, Sousa and Vieira (2018), it is not enough to simply allocate resources to administer a university, one must consider the complexity of managing this type of institution, which involves necessary participatory planning and body of qualified servers.

Soares and Melo (2017) state that the IDP has as its main objective, the design of new practices to improve its strategic management model and point to the different profiles of a macroinstitutional nature, such as: the teaching, research and extension activities of each institution university.

Luz (2016), when researching the IDP of the Federal University of Santa Catarina, as this is the institution's planning instrument, identifies and highlights the following objectives:

Ensure the quality of teaching at all levels, seeking new levels of academic excellence: institutionalize innovative actions in pedagogical projects at all levels of education; establish a policy of reception, monitoring and pedagogical support for students (undergraduate and graduate); expand qualified access and the effectiveness of formative processes; promote interaction actions with graduates and establish an educational accessibility policy (Luz, 2016, p. 113, our translation).

Dal Magro \& Rausch (2012) state that the Institutional Development Plan is a requirement for accreditation and re-accreditation of higher education institutions and may also be required under the supervision actions carried out by the Higher Education Secretariat (SeSU/MEC).

The Ministry of Education (MEC), through the Process Monitoring System of Higher Education Institutions (SAPIENS/MEC), published a document intended to serve as a reference for the construction of the IDP, answering doubts and questions from the HEls (Dal Magro \& Rausch, 2012). Thus, the preparation of the document must meet the following dimensions: institutional profile, institutional management, academic organization, infrastructure, financial and budgetary aspects, evaluation and monitoring of institutional development and annexes.

In this sense, Freire and Mendonça (2018) indicate the percentage of Federal Universities that reference in their Institutional Development Plans (IDP) the theme monitoring of graduates, from the 63 Federal Universities, $86 \%$ included the theme researched in different dimensions of the IDP, 11\% do not refer and 3\%, 2 universities, are in the process of preparing their first IDP. The authors conclude that all the HEls surveyed make their IDPs available on their websites, an extremely important aspect, considering the recent advances in the implementation of a culture of transparency and access to information in public agencies, which gradually provide for the increase of the social control.

Table 1 provides an overview of the indicators of the Institutional Management Dimension of the IDP.

Table 1. Overview of the indicators of the Institutional Management Dimension of the IDP.

\begin{tabular}{cl}
\hline Dimension & \multicolumn{1}{c}{ Institutional Management } \\
\hline 1 & Organizational structure, decision-making body and institutional and academic organization chart; \\
2 & Collegiate bodies: Attributions, competences and composition; \\
3 & Supporting bodies for academic activities; \\
4 & Autonomy of the HEI in relation to the maintainer; \\
5 & Relationships and partnerships with the community, institution and companies; \\
\hline
\end{tabular}




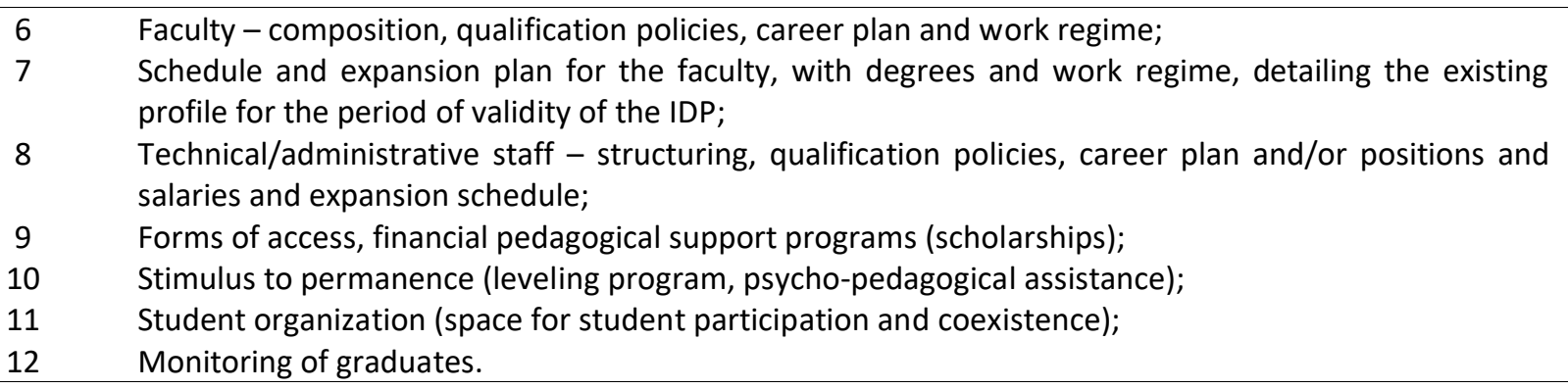

Source: Devised by the author from the information made available in the INEP/MEC website (2018).

Table 1 describes the indicators of the Institutional Management dimension, one of the dimensions that should be structured in the preparation of the IDP and which has 12 indicators, as described in the table. It is noted in indicator 12, the forecast of follow-up of graduates.

\section{RESULTS AND ANALYSIS}

\section{Follow-up perspectives inserted in the IDPs}

The information collected in the table with the main data obtained from the universities' websites is presented below, showing an overview of how these institutions present the information to the general public in their IDPs, and how they plan to develop actions and goals for the topic. Table 2 describes the actions proposed by the Federal Universities of the Southeast region to monitor their graduates:

Table 2. Actions proposed by the Federal Universities of the Southeast region to monitor their graduates.

\begin{tabular}{|c|c|}
\hline HEI & Institutional propositions \\
\hline UFJF & - Outline an institutional policy for monitoring graduates to gather information from Academic Units. \\
\hline UFLA & $\begin{array}{l}\text { - Conduct studies on the graduates and the implications for the development of courses; } \\
\text { - Raise data on the actions of other Federal Institutes of Education on the subject; } \\
\text { - Generate channels of dialogue with graduates; } \\
\text { - Collect data; } \\
\text { - Organize information to support decisions by collegiate bodies about the curriculum of courses. }\end{array}$ \\
\hline UFMG & $\begin{array}{l}\text { - Instituting diversified mechanisms that strengthen UFMG's links with its graduates; } \\
\text { - Encourage the realization of studies on graduates of the Undergraduate and Postgraduate courses at } \\
\text { UFMG. }\end{array}$ \\
\hline UFOP & $\begin{array}{l}\text { - Encouragement to carry out studies on graduates from undergraduate and postgraduate courses; } \\
\text { - Development of a permanent monitoring program for graduates. }\end{array}$ \\
\hline UFSCar & $\begin{array}{l}\text { - Improve the monitoring mechanisms of University graduates foreseen in the institutional assessment } \\
\text { processes; } \\
\text { - Promote mechanisms that favor the contribution of graduates to university life, including for the } \\
\text { formation of future professionals. }\end{array}$ \\
\hline UFSJ & $\begin{array}{l}\text { - Identify the profile of graduates and create mechanisms to assess their performance in jobs, whether } \\
\text { in the public, private or third sector; } \\
\text { - Build a database with information that makes it possible to maintain permanent communication and a } \\
\text { close institutional bond with the graduate; } \\
\text { - Foster the relationship between the university and its graduates, aiming at the improvement of } \\
\text { institutional actions concerning the implementation of courses and programs within the scope of higher } \\
\text { education; } \\
\text { - Obtain information from employers that, associated with those of the graduates, guide institutional or } \\
\text { course decision-making; }\end{array}$ \\
\hline
\end{tabular}


- Stimulate and create conditions for continuing education;

- Build indicators that support curriculum adaptation to the needs of developing skills and abilities in line with national guidelines for higher education courses;

- Promote academic updating by offering courses, seminars and lectures aimed at the professional complementation of the graduate;

- Integrate the graduate to the academic community through participation in artistic, cultural and sporting events promoted by the University;

- Provide the participation of graduates in extension activities (as proponent of extension courses, speaker/lecturer at academic and scientific events, and as a collaborator in social responsibility activities);

- Offer and publicize the benefits policy aimed at UFSJ graduates;

- Supporting graduates in labor market and employability issues;

- Disclose possibilities and possible job vacancies;

- Provide the graduate with space for socialization and dissemination of contributions to society (conquests, awards, and artistic and literary production);

- Enable and promote the relationship between former classmates, as well as any meetings between the classes;

- Capture information, through its own tool, to build indicators that will support the institutional policy for monitoring the graduates.

- Create aggregating environments for graduates to maintain their institutional bonds;

UNIFESP - Systematically evaluate the professional insertion of graduates from different courses, programs and research projects;

- Review and update programs, projects and course plans, induced by the evaluation of the graduates' professional insertion.

\begin{tabular}{cl}
\hline UFU & - Implement a project to monitor graduates. \\
\hline UFV & - Improve monitoring and interaction with graduates; \\
& - Develop a monitoring system for UFV graduates. \\
\hline UFES & - Implement a graduate monitoring program. \\
\hline UNIRIO & - Expand the follow-up of graduates and bring them closer to UNIRIO; \\
& - Create a biannual meeting of UNIRIO graduates. \\
\hline UFRRJ & - Develop instruments to monitor graduates; \\
& - Implement a virtual monitoring system for graduates; \\
\hline UNIFAL & - Permanently analyze the data obtained. \\
\hline & $\begin{array}{l}\text { - Implement the Support and Integration Program for Graduates; } \\
\text { UNIFEI }\end{array}$ \\
& $\begin{array}{l}\text { of graduates; } \\
\text { - Promote changes and updates in the pedagogical projects of undergraduate and graduate courses as a } \\
\text { result of alumni evaluations. }\end{array}$ \\
\hline
\end{tabular}

UFABC already graduated from some undergraduate and/or postgraduate course at the University, even if they are continuing in other undergraduate or postgraduate courses at the Institution (once a student at UFABC, forever a student at UFABC).

Source: Devised by the authors based on the data available in the HEls websites (2018)

Analyzing Table 2, it appears that $10 \mathrm{HEls}$ list at least more than one action aimed at monitoring, although the institutionalization of the policy is recent in the country, intentionality is observed as a constitutive element in the systematization of proposals in the Southeast region, to which they suggest specific steps to achieve objectives and goals according to the IDP schedule.

Occasionally, the following HEIs, UNIFEI, UFSJ and UNIFESP, insert the perspective of systematic monitoring of the professional insertion of graduates. Thus, the university/labor market integration is essential as a source of information for the HEl that formed them. For Andriola (2014), 
nothing is more important than investigating the social repercussions of the activities of a HEI, through the systematic monitoring of its graduates, seeking to know the attitudes, beliefs and culture about the academic community and society, identifying and evaluating the value added by the HEI.

UNIFEI, UFLA, UFSJ, UNIFESP indicate the relevance of updates, changes, implications of their curricula and pedagogical projects, through the capture of information. Often, because they do not receive this information, HEls do not obtain the necessary feedback for evaluating the teaching offered, do not reflect their pedagogical practices and fail to make changes, adjustments to the content taught.

Another relevant follow-up action would be to hold an annual or biannual meeting of graduates combined with scientific events at the university to increase the interest of the external community, including former students, an action provided for in the planning of UFSJ and UNIRIO.

Specifically, the UFMG and UFOP universities refer to the need to carry out studies on graduates from undergraduate and postgraduate courses, taking advantage of opportunities, including, to obtain positive feedback from this, for example, using the results to improve academic actions. Machado (2010) states that the use of consultation mechanisms for graduates brings together aspects of external assessment, as post-graduate assessment allows for a critical look and internal assessment, as the academic community experiences the weaknesses and qualities of the courses daily. For UFLA, UFSJ, UFV, UFRRJ, it is necessary to build a database, since reliability in receiving data is essential to obtain information that will allow for future analyses.

UFSCAR, UFMG, UFV, UFRRJ and UNIFAL point to the improvement of monitoring mechanisms and instruments that contribute to institutional assessment, thus, they would be aligned with the National System for Higher Education Assessment (SINAES), which proposes a procedural, systematic and integrated institutional assessment by several complementary instruments. As for the procedures provided for in the SINAES Law, the processes must be legitimized through the democratic and conscious participation of all those involved, especially regarding the production of socially valid knowledge (Machado, 2010).

Some universities such as UFLA, UFABC, UNIRIO and UNIFESP highlight the importance of generating channels for permanent dialogue, there is an emphasis on demand, on the part of UFABC, by evidencing in its motto: "once a student at UFABC, forever a student at UFABC"; another HEl that demonstrates the culture of institutional return is UFMG, with its "Always UFMG Program". It is necessary to establish a dialogue to know the opinion of employers and other sectors of organized civil society, about the adequacy and relevance of professional and citizen training of graduates (Andriola, 2014).

UFLA points to the need to investigate actions developed by other HEls on the subject, an admissible initiative in the conception of similarities existing between the various higher education institutions. Although fundamental principles of the SINAES law, such as recognition of the diversity of the system and respect for the identity, mission and history of institutions, refer to the specificities of institutions, it is necessary to recognize actions and initiatives of other institutions that reflect the success, good practices and be considered as a reference.

Furthermore, some institutions may be developing specific actions in their courses, programs or faculties to get to know the opinion of their alumni that are not widely publicized or known by the entire academic community but that represent successful initiatives. Therefore, the UFJF intends to gather information from the various Academic Units.

In the Southeast region, the university that most detailed the actions it intends to develop, in the interstice of its current PDI, was the UFSJ, as it described other objectives not previously mentioned by other HEls, such as: promoting updating of the academic community through participation in artistic events, cultural and sporting activities, offer a benefits policy, provide the graduates with space for socialization and dissemination of achievements, awards and artistic and 
literary production, provide the participation of graduates in extension activities, such as proponent of extension courses, speaker/lecturer at academic and scientific events, and as a collaborator in social responsibility activities.

Completing the information from the Southeast region, it was observed that UFRJ, UFTM, UFVJM and UFF do not reference or do not describe goals, objectives or indicators for monitoring.

Table 3 is presented below, with a summary of the main implementation and development actions provided for in the IDPs of federal universities in the Southeast region.

Table 3. Summary of the main implementation and development actions provided for in the IDPs of federal universities in the Southeast region.

\begin{tabular}{|c|c|}
\hline Actions for implementation & Actions for development \\
\hline Outline an institutional policy for graduates & $\begin{array}{l}\text { Monitor the academic and professional performance of } \\
\text { graduates }\end{array}$ \\
\hline $\begin{array}{l}\text { Create conditions for continuing education for } \\
\text { graduates }\end{array}$ & $\begin{array}{l}\text { Increase the extension actions with the formation of } \\
\text { transforming agents with the integration between students } \\
\text { and graduates. }\end{array}$ \\
\hline Create periodic alumni meetings & $\begin{array}{l}\text { Promote academic/society/company integration activities } \\
\text { involving undergraduate and postgraduate students }\end{array}$ \\
\hline Build a database & Keep an open channel with graduates \\
\hline $\begin{array}{l}\text { Collect data on the actions of other Federal } \\
\text { Institutes of Education on the topic }\end{array}$ & Promote meetings between former classmates \\
\hline $\begin{array}{l}\text { Approve a document containing the institutional } \\
\text { assessment policy for alumni monitoring }\end{array}$ & $\begin{array}{l}\text { Develop actions to support course coordinators regarding the } \\
\text { monitoring of graduates }\end{array}$ \\
\hline Conduct research on graduates & $\begin{array}{l}\text { Expand the debate on the relationships between the } \\
\text { graduate, the job market and the field of action }\end{array}$ \\
\hline Create aggregating environments for graduates & Strengthen the institutional bond of the alumni \\
\hline $\begin{array}{l}\text { Offer the graduate, through the Portal, updated } \\
\text { information about courses, activities such as social } \\
\text { meetings and civic events, employment } \\
\text { opportunities, entrepreneurship actions, among } \\
\text { others }\end{array}$ & $\begin{array}{l}\text { Review and update course plans, induced by the assessment } \\
\text { of the graduates' professional insertion }\end{array}$ \\
\hline $\begin{array}{l}\text { Create a methodology for monitoring graduates, in } \\
\text { accordance with SINAES guidelines }\end{array}$ & $\begin{array}{l}\text { Improve the mechanisms provided for in institutional } \\
\text { assessment processes }\end{array}$ \\
\hline Create an Egress Portal on the institutional website & Maintaining an Egress Portal \\
\hline
\end{tabular}

In Table 3, the main objectives in the plans to implement and develop are observed, we tried to insert in the table the corresponding actions in relation to the elaboration and continuity of the proposed actions, as important as implementing is to follow up and monitor, overcoming stages and applying new methodologies, seeking to adapt the monitoring to the characteristics of the target audience, which differs in each local context and which, over time, brings new perspectives and demands.

From the list of institutional proposals of the IDPs, whether through the formalization of a resolution or the creation of a portal or even in the scope of exposing different and innovative methodologies, there is a high effort to set the creation of a policy as a goal. The university must be attentive to, through its planning and management acts, achieve greater, better results, and allow research on graduates to serve as a basis for other planning (Machado, 2010).

\section{FINAL CONSIDERATIONS}

This work sought to identify the actions and goals provided for in the IDPs of Brazilian federal universities in the Southeast region for monitoring their graduates. In addition, aspects of university management, planning and institutional assessment in the Brazilian context were verified, through the implementation of the SINAES Law, as institutions tend to incorporate the most important 
indicators, which bring immediate return on financing, and which are effectively more demanded by regulatory agencies. These are topics to be included in planning, programs and projects, so there are huge challenges to institutionalize the follow-up of graduates.

With the study, it was possible to verify the efforts of institutions to establish goals and objectives related to their IDPs, a positive aspect due to the relevance of the macro-document in planning, which aims to establish guidelines and priorities in the short, medium and long term.

Therefore, after analyzing the survey in these institutions, it is interesting to highlight that the majority included the theme in the IDP, there is clarity in the objectives of two main groups, especially in the actions to achieve goals: a group that aims to implement and another group that will use new practices for having already implemented and advanced to other stages, the present analysis highlights the details of some universities in their planning, as this knowledge is already applied and institutionalized.

Furthermore, based on this survey, some possible findings can be made, as essential tools for maintaining the bond are presented: the creation of a channel and a database that allows permanent communication and monitoring of the academic and professional performance of students.

Finally, the teaching, research and extension actions inserted in the various segments of the institution and dimensioned by axes in the IDPs, refer to the specificity of the choices with their clear objectives, goals and schedule and to the role of this document in the planning of universities, including the study of the professional and academic trajectory of graduates.

Authors' Contributions: Freire, L. F. S.: conception and design, acquisition of data, analysis and interpretation of data, drafting the article, critical review of important intellectual content; Souza, K. R.: conception and design, acquisition of data, analysis and interpretation of data, drafting the article, critical review of important intellectual content. The authors have read and approved the final version of the manuscript.

Ethics Approval: Not applicable.

Acknowledgments: Not applicable.

\section{REFERENCES}

Andriola, W. B. (2014). Estudo de egressos de cursos de graduação: subsídios para a autoavaliação e o planejamento institucionais. Educar em Revista, 54, 203-219.

Batista, Z. N., \& Kerbauy, M. T. M. (2018). A gênese da extensão universitária brasileira no contexto de formação do ensino superior. Revista Ibero-Americana de Estudos em Educação, 13(3), 916-930.

Batistti, T. S., Preto, V. M., \& Heinzle, M. R. S. (2017). Processos avaliativos na Educação Superior: os planos de ensino em análise. Revista Ibero-Americana de Estudos em Educação, 12(3), 1774-1791.

Bizerril, M. X. A. (2020). O processo de expansão e interiorização das universidades federais brasileiras e seus desdobramentos. Revista Tempos e Espaços em Educação, 13(32), p. 1-15.

Brasil (1996). Lei n.o 9.394, de 20 de dezembro de 1996. Estabelece a Lei de Diretrizes e Bases da Educação Nacional. Brasília: Presidência da República, 1996. Available at: http://www.planalto.gov.br/ccivil 03/leis/19394.htm

Brasil (2003). Ministério da Educação. SINAES. Bases para uma Nova proposta da Educação Superior. Brasília, 2003. Available at: http://portal.mec.gov.br/arquivos/pdf/sinaes.pdf

Brasil (2004). Lei n. 10.861, de 14 de abril de 2004. Institui o Sistema Nacional de Avaliação da Educação Superior SINAES e dá outras providências. Brasília: Presidência da República, 2004. Available:

http://www.planalto.gov.br/ccivil 03/ ato2004-2006/2004/lei/l10.861.htm

Brasil (2006). Decreto n. 5.773, de 9 de maio de 2006. Dispõe sobre o exercício das funções de regulação, supervisão e avaliação de instituições de educação superior e cursos superiores de graduação e sequenciais no sistema federal de ensino. Revogado pelo Decreto n. 9.235, de 15 de dezembro de 2017. Brasília: Presidência da República, 2006.

Available at: http://www.planalto.gov.br/ccivil 03/ ato2004-2006/2006/decreto/d5773.htm 
Brasil (2009). Ministério do Planejamento. Orçamento e Gestão. Produto 4: guia referencial para medição de desempenho e manual para construção de indicadores. Brasília: [s.n.], 2009. Available at:

http://www.gespublica.gov.br/sites/default/files/documentos/guia_indicadores jun2010.pdf

Dal Magro, C. B., \& Rausch, R. B. (2012). Plano de desenvolvimento institucional de universidades federais brasileiras. 2012. Administração: Ensino e Pesquisa, 3(3). 427-454.

Costa, A. G., \& Vidal, E. M. (2020). Concepções e implicações da accountability educacional no Brasil: o estado da questão (2006-2018). Revista Tempos e Espaços em Educação, 13(32), 1-23.

Dias, P. H. R. C., Sousa, J. C., \& Vieira, C. C. F. (2017). Estratégia institucional: relação entre o PDI, PPI e planejamento estratégico no IFB. Revista on line de Política e Gestão Educacional, 21(2), 334-349.

Dias Sobrinho, J. (2010). Avaliação e transformações da educação superior brasileira (1995 - 2009): do provão ao SINAES. Revista Avaliação, 15(1), 195-224.

Dias Sobrinho, J. (2015). Universidade fraturada: reflexões sobre conhecimento e responsabilidade social. Avaliação, 20(3), 581-601.

Freire, L. F. S. \& Mendonça, J. C. A. (2018). Plano de Desenvolvimento Institucional nas universidades federais: os rumos do acompanhamento de egressos. XLII Encontro da ANPAD - EnANPAD. 2018, Curitiba

GIL, A. C. (2002). Como elaborar projetos de pesquisa. São Paulo: Altas.

Inep (2003). Bases para uma nova proposta de avaliação da Educação Superior. Sistema Nacional de Avaliação da Educação Superior. Brasília: INEP. Available at: http://portal.mec.gov.br/arquivos/pdf/sinaes.pdf

Inep (2004). Plano Nacional de Educação: Política de Estado para a educação brasileira. Sistema Nacional de Avaliação da Educação Superior. Brasília: INEP. Available at:

http://download.inep.gov.br/download/superior/sinaes/orientacoes sinaes.pdf

Inep (2015). Política Institucional de integração e de avaliação do egresso na melhoria da IES. Sistema Nacional de Avaliação da Educação Superior. Brasília: INEP, 2015. Available at:

http://portal.inep.gov.br/documents/186968/484109/SINAES+-

+Sistema+Nacional+de+Avalia\%C3\%A7\%C3\%A3o+da+Educa\%C3\%A7\%C3\%A3o+Superior+Vol+3/4aa14291-0451-4017b280-19f313eb4116?version=1.0

Inep (2019). Censo da Educação Superior 2018: notas estatísticas. Brasília: INEP.

LUZ, S. R. (2016). Plano de desenvolvimento institucional - PDI como ferramenta de gestão para os cursos de graduação da universidade federal de Santa Catarina. 2016. 168 f. Dissertação (Mestrado) - Universidade Federal de Santa Catarina, Santa Catarina, SC, Brasil.

Machado, G. R. (2010). Perfil do egresso da Universidade Federal do Rio Grande do Sul. 2010. 338 f. Tese (Doutorado em Educação) - Universidade Federal do Rio Grande do Sul, Porto Alegre, RS, Brasil.

Mizael, G. A., Vilas Boas, A. A., Pereira, J. R., \& Santos, T. S. (2013). Análise do Plano de Desenvolvimento Institucional das universidades; federais do Consórcio Sul-Sudeste de Minas Gerais. Revista de Administração Pública, 47(5), 11451164 .

Picawy, M. M. (2007). PDI - Plano de Desenvolvimento Institucional, PPI - Projeto Pedagógico Institucional e PPC Projeto Pedagógico de Curso, entre o dito e o feito, uma análise da implementação em três IES/RS/Brasil. Tese (Doutorado em Educação) - Pontifícia Universidade Católica do Rio Grande do Sul, Porto Alegre, RS, Brasil.

Soares, M. L.; Melo, P. A. (2017). Processo de formulação de estratégias: um estudo comparativo entre duas Universidades Públicas. Revista da UNIFEBE, 1(22), 1-20.

Sobral, M. N., \& Ramos, N. (2012). Processo de Bolonha internacionalização do ensino superior. Revista Tempos e Espaços em Educação, 5(8), 1-12.

Souza, K. R. (2017). Direito à educação nos países membros do Mercosul: um estudo comparado. Tese (Doutorado em Educação Escolar) - Universidade Estadual Paulista, Araraquara, SP, Brasil.

Received: 15 May 2021 | Accepted: 3 August 2021 | Published: 23 August 2021

This is an Open Access article distributed under the terms of the Creative Commons Attribution License, which permits unrestricted use, distribution, and reproduction in any medium, provided the original work is properly cited. 